\title{
Efektivitas antibakteri gel chitosan dengan berat molekul berbeda terhadap jumlah koloni bakteri Streptococcus mutans pada permukaan email sekitar braket ortodonti
}

\author{
Della Noor Insany ${ }^{1}$, Haru Setyo Anggani ${ }^{*}$, Widya Kusumadewi ${ }^{1}$
}

${ }^{1}$ Departemen Ortodonsia, Fakultas Kedokteran Gigi Universitas Indonesia, Indonesia

*Korespondensi: haruanggani@yahoo.com

Submisi: 10 Maret 2021; Penerimaan: 24 Desember 2021; Publikasi online: 27 Desember 2021

DOI: $\underline{10.24198 / j k g . v 33 i 3.32598}$

\begin{abstract}
ABSTRAK
Pendahuluan: Chitosan merupakan bahan alami, bersifat antibakteri, dan dapat dibentuk menjadi gel sehingga berpotensi sebagai agen profilaksis terhadap Streptococcus mutans, penyebab demineralisasi email. Lesi white spot merupakan salah satu risiko penggunaan alat ortodonti cekat. Berat molekul merupakan salah satu faktor yang memengaruhi efektivitas antibakteri chitosan, namun hubungannya masih memberikan hasil yang inkonsisten. Penelitian ini bertujuan menganalisis perbedaan efektivitas gel chitosan dengan berat molekul berbeda terhadap jumlah koloni bakteri Streptococcus mutans pada permukaan email sekitar braket ortodonti. Metode: Penelitian ini menggunakan metode eksperimen laboratoy dengan menggunakan 24 sampel gigi dengan braket dioles gel chitosan A (50-80 kDa), gel chitosan B (50-150 kDa), gel chitosan C (190-310 kDa), dan gel kontrol klorheksidin diglukonat $0,2 \%(\mathrm{CHX})$ masing-masing 6 sampel. Seluruh sampel diinkubasi dalam biakan Streptococcus mutans secara bertahap, $10 \mu \mathrm{l}$ suspensi dari plak yang terbentuk pada sampel dibiakkan untuk memperoleh koloni pada biakan agar. Data dianalisis dengan uji one-way ANOVA dan Least Significant Difference (LSD). Hasil: Jumlah koloni bakteri Streptococcus mutans setelah aplikasi gel chitosan A, B, C, dan gel klorheksidin diglukonat

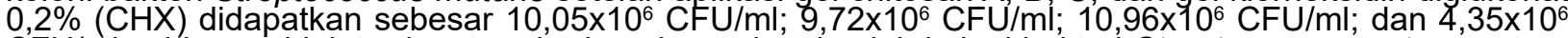
CFU/ml sehingga tidak terdapat perbedaan bermakna jumlah koloni bakteri Streptococcus mutans antara ketiga kelompok gel chitosan $(p>0,05)$ dan terdapat perbedaan jumlah koloni bakteri Streptococcus mutans yang bermakna antara ketiga gel chitosan dengan gel kontrol $(p<0,05)$. Simpulan: Efektivitas antibakteri gel chitosan dengan berat molekul berbeda terhadap jumlah koloni bakteri Streptococcus mutans pada permukaan email sekitar braket ortodonti adalah sama besar, namun lebih rendah daripada efektivitas antibakteri gel klorheksidin diglukonat $0,2 \%$ pada studi ini.
\end{abstract}

Kata kunci: berat molekul; braket ortodontik; kitosan; email; Streptococcus mutans

\section{Antibacterial effectiveness of chitosan gel with different molecular weights on the number of Streptococcus mutans colonies in the enamel surface around orthodontic bracket}

\begin{abstract}
Introduction: Chitosan is a natural ingredient, antibacterial, and can be formed into a gel so that it has the potential as a prophylactic agent against Streptococcus mutans, the cause of enamel demineralization. White spot lesions are one of the risks of using fixed orthodontic appliances. Molecular weight is one factor that affects the antibacterial effectiveness of chitosan, but the relationship still gives inconsistent results. This study aimed to analyze the differences in the effectiveness of chitosan gels with different molecular weights on the number of Streptococcus mutans bacteria colonies on the enamel surface around orthodontic brackets. Methods: This study used an experimental laboratory method using 24 dental samples with brackets smeared with chitosan A gel (50-80 kDa), chitosan B gel (50-150 kDa), chitosan C gel (190-310 kDa), and chlorhexidine control gel. digluconate $0.2 \%$ (CHX) each of 6 samples. All samples were incubated in Streptococcus mutans culture in stages, 10 I suspension of the plaque formed on the samples was cultured to obtain colonies on agar cultures. Data were analyzed by one-way ANOVA and Least Significant Difference (LSD). Results: The number of Streptococcus mutans colonies after application of chitosan gel $A, B, C$, and $0.2 \%$ chlorhexidine digluconate $(\mathrm{CHX})$ gel was $10.05 \times 106 \mathrm{CFU} / \mathrm{ml}$; 9.72×106 CFU/ml; $10.96 \times 106 \mathrm{CFU} / \mathrm{ml}$; and $4.35 \times 106 \mathrm{CFU} / \mathrm{ml}$, so that there was no significant difference in the number of Streptococcus mutans colonies between the three chitosan gel groups $(p>0.05)$ and there was a significant difference in the number of Streptococcus mutans bacteria colonies between the three chitosan gels and the control gel $(p<0.05)$. Conclusions: The antibacterial effectiveness of chitosan gel with different molecular weights on the number of Streptococcus mutans bacterial colonies on the enamel surface around orthodontic brackets was simi-lar but lower than the antibacterial effectiveness of $0.2 \%$ chlorhexidine digluconate gel.
\end{abstract}

Keywords: molecular weight; orthodontic bracket; chitosan; enamel; Streptococcus mutans 


\section{PENDAHULUAN}

Maloklusi merupakan hubungan antara gigi-gigi rahang atas dengan rahang bawah yang tidak harmonis sehingga fungsi stomatognatik terganggu dan tampilan gigi-gigi menjadi kurang estetis. Kondisi tersebut akan memengaruhi kualitas hidup seseorang. ${ }^{1,2,3,4}$ Perawatan ortodonti diperlukan untuk mengoreksi kondisi tersebut agar fungsi stomatognatik seperti fungsi pengunyahan, bicara, dan penelanan kembali normal. Perawatan ortodonti cekat merupakan salah satu metode yang digunakan untuk mengoreksi maloklusi, tetapi memiliki risiko yang sulit dihindari yaitu retensi plak pada email sekitar braket ortodonti yang memicu terbentuknya lesi karies dini atau lesi white spot sebagai hasil demineralisasi email oleh bakteri Streptococcus mutans yang memberikan efek negatif terhadap estetika gigi. ${ }^{5,6}$ Kebersihan rongga mulut perlu ditingkatkan untuk mencegah hal tersebut di atas.

Terdapat dua cara untuk menghambat pembentukan plak di sekitar braket ortodonti yaitu secara mekanis dan kimiawi selain dental health education (DHE). Secara mekanis yaitu dengan menyikat gigi secara teratur dan secara kimiawi yaitu dengan penggunaan agen profilaksis topikal seperti larutan kumur, varnish, pasta gigi, dan gel. Beberapa bahan aktif yang umumnya terkandung di dalam agen profilaksis topikal yang dapat mengurangi kemungkinan terjadinya lesi white spot pada pengguna alat ortodonti cekat adalah fluoride, casein phosphopeptide-amorphous calcium phosphate (CPP-ACP) serta klorheksidin. ${ }^{7}$ Salah satu gel yang dapat menghambat pembentukan plak pada permukaan email di sekitar braket ortodonti adalah gel klorheksidin $2 \% .{ }^{8}$ Klorheksidin memiliki kekurangan yaitu dapat menyebabkan gangguan pengecapan rasa, terbentuknya lesi deskuamasi pada mukosa oral, serta diskolorasi gigi, restorasi, dan lidah. ${ }^{9}$

Beberapa kekurangan yang dimiliki oleh klorheksidin mendorong peneliti berupaya untuk mencari agen antibakteri lain yang dapat digunakan sebagai alternatif pengganti klorheksidin yang lebih aman. Salah satu bahan alami yang saat ini banyak diteliti adalah chitosan. Chitosan adalah senyawa polimer kationik turunan chitin yang bersifat biodegradable, biocompatible, serta nontoksik. ${ }^{10}$ Chitosan dikenal memiliki sifat antibakteri karena ia terbukti mampu melawan bakteri Gram-positif maupun Gram-negatif. ${ }^{11}$ Sifat antibakteri chitosan dipengaruhi oleh konsentrasi, berat molekul, densitas muatan positif/derajat deasetilasi, karakteristik hidrofobik/hidrofilik, tipe mikroorganisme, suhu dan waktu, $\mathrm{pH}$, keadaan fisik chitosan, kapasitas kelasi, dan kekuatan ionik, namun berat molekul chitosan merupakan faktor yang masih harus diteliti karena hubungannya dengan sifat antibakteri chitosan masih memberikan hasil yang inkonsisten. Beberapa penelitian mengatakan bahwa efektivitas antibakteri chitosan berbanding lurus dengan berat molekulnya, namun terdapat juga beberapa penelitian yang mengatakan hal sebaliknya. ${ }^{12}$ Berdasarkan berat molekulnya, chitosan dibagi menjadi tiga yaitu chitosan berat molekul rendah, sedang, dan tinggi. ${ }^{11}$ Peneliti ini bertujuan menganalisis sifat antibakteri dari gel chitosan dengan berat molekul yang berbeda terhadap bakteri Streptococcus mutans yang terdapat pada plak yang terbentuk di sekitar permukaan braket ortodonti sehingga dapat ditemukan agen profilaksis topikal alternatif pengganti klorheksidin.

\section{METODE}

Sampel penelitian adalah gigi-gigi premolar satu atau dua, baik atas maupun bawah yang belum pernah di-bonding, tidak ada tumpatan, tidak ada abnormalitas, bebas stain, bebas lesi white spot, bebas crack dan karies, dan bebas defek karena proses ekstraksi serta terpilih secara acak sebagai sampel. Penelitian dimulai dengan pengumpulan saliva negatif COVID-19, pembuatan biakan cair Brain Heart Infusion (BHI) + sukrosa $1 \%$, pembuatan gel chitosan, teknik sampling, persiapan spesimen, pengujian spesimen, serta pembiakan dan uji hitung koloni $S$. mutans pada media agar. Saliva untuk penelitian diperoleh dari sampel saliva peneliti yang telah dinyatakan negatif COVID-19 melalui uji swab nasofaring dan orofaring. Sampel dikumpulkan dengan metode draining. ${ }^{13}$

Pembuatan biakan cair BHI-Sukrosa $1 \%$ dilakukan dengan cara mendispersikan biakan bakteri S. mutans ATCC 25175 ke dalam broth BHI-Sukrosa $1 \%$ dan diinkubasi selama 24 jam pada suhu $37^{\circ} \mathrm{C}$ dengan kondisi anaerob. Jumlah bakteri dalam suspensi distandardisasikan dengan 
nilai absorbansi ekuivalen dengan jumlah $10^{8} \mathrm{sel} /$ $\mathrm{ml}$.

Chitosan dengan tiga berat molekul yang berbeda menurut ketersediaan bahan oleh supplier yaitu 50-80 kDa, 50-150 kDa, dan 190-310 kDa dibuat dengan konsentrasi $3 \% \mathrm{w} / \mathrm{w}$ dengan cara mencampurkan bubuk chitosan sebanyak 0,3 gram dengan larutan asam asetat $1 \%$ sebanyak 9,7 gram di dalam gelas ukur yang diletakkan di atas hot plate dengan suhu $80-85^{\circ} \mathrm{C}$. Setelah homogen, larutan $\mathrm{NaOH} 1 \mathrm{M}$ diteteskan sedikit demi sedikit hingga semua gumpalan yang terbentuk terlarut dan nilai $\mathrm{pH}$ gel mencapai 6,0 . Gel disimpan di dalam tube gel pada suhu $2-8^{\circ} \mathrm{C}$.

Teknik sampling dilakukan dengan mengambil 24 gigi secara acak dari total 30 gigi yang terkumpul. Setelah gigi sampel terpilih, mahkota gigi sampel dipisahkan dari akarnya dan ditanam di dalam pipa PVC yang telah diolesi dengan vaseline dan diisi dengan dental stone dengan posisi sisi bukal gigi menghadap ke atas. Gipsum dilepaskan dari pipa setelah mengeras dan menggunakan amplas kasar setiap permukaannya dihaluskan. Sisi bukal gigi dipasang braket edgewise standar pada pertengahan sumbu fasial gigi.

Setiap spesimen gigi diberi nomor sehingga terdapat spesimen gigi dengan nomor 1 hingga 24 dan kemudian disterilisasi dengan autoklaf. Seluruh sampel dibagi menjadi empat perlakuan yang berbeda yaitu gel chitosan $A(50-80 \mathrm{kDa})$, gel chitosan $B(50-150 \mathrm{kDa})$, dan gel chitosan $C$ (190-310 kDa) sebagai kelompok perlakuan, dan gel klorheksidin diglukonat $0,2 \%(\mathrm{CHX})$ sebagai kelompok kontrol. Pengujian dilakukan dengan teknik single-blind. Seluruh tube gel diberikan kode $a, b, c$, dan d secara acak. Misalnya kode a untuk gel chitosan $B$, kode b untuk gel chitosan $C$, dan seterusnya.

Seluruh spesimen gigi dirandomisasi. Randomisasi dilakukan untuk membagi spesimen secara acak ke dalam empat kelompok perlakuan yang berbeda-beda. Saliva negatif COVID-19 dikeluarkan dari freezer dan dibiarkan mencair. Saliva yang sudah mencair disentrifugasi selama 15 menit dengan kecepatan $3000 \mathrm{rpm} / 1500 \times \mathrm{g}$ untuk memisahkan cairan saliva dari sedimen saliva. Setiap spesimen dioles saliva pada bagian email dan braket ortodonti dan dibiarkan selama 1 jam, lalu dibilas dengan larutan Phosphate Buffered
Saline (PBS) steril. Spesimen gigi diolesi gel (gel chitosan $A, B, C$, dan gel kontrol klorheksidin diglukonat $0,2 \%$ ) sesuai kelompok perlakuannya dan dibiarkan selama 5 menit. ${ }^{14}$ Seluruh spesimen gigi direndam di dalam broth $\mathrm{BHI}-S u k r o s a 1 \%$ dan diinkubasi selama 8 jam dalam suhu $37^{\circ} \mathrm{C}$ dengan kondisi anaerob. Seluruh spesimen gigi kemudian direndam dalam broth $\mathrm{BHI}$ tanpa sukrosa dan diinkubasi selama 24 jam dalam suhu $37^{\circ} \mathrm{C}$ dengan kondisi anaerob. ${ }^{15}$

Setiap spesimen diangkat dari dalam rendaman. Plak yang terbentuk di sekitar braket ortodonti dikerok menggunakan sonde steril lalu diletakkan di dalam eppendorf tube yang berisi larutan PBS. Tube tersebut di-vortex hingga homogen dan dilakukan pengenceran berseri secara bertahap. Sebanyak $10 \mu \mathrm{l}$ dari pengenceran berseri yang ditentukan ditanam pada agar $\mathrm{BHI}$. Agar tersebut diinkubasi selama 48 jam dalam suhu $37^{\circ} \mathrm{C}$ di dalam anaerobic jar. Koloni S. mutans yang terbentuk dihitung dengan alat colonycounter. Hasil yang diperoleh dikalikan dengan faktor pengenceran yang digunakan.

Data yang diperoleh dilakukan uji normalitas menggunakan uji Shapiro-WIlk. Uji statistik yang digunakan adalah uji parametrik one-way ANOVA. Sebelumnya, data dilakukan uji Homogenity of Variance terlebih dahulu untuk memenuhi syarat uji parametrik one-way ANOVA yaitu distribusi data normal dan varians data homogen. Jika uji Homogenity of Variance menghasilkan nilai $p>0,05$, maka data dapat diuji dengan uji parametrik one-way ANOVA. Namun, jika uji Homogenity of Variance menghasilkan nilai $p<0,05$, maka data dilakukan uji homogenitas alternatif yaitu uji Brown-Forsythe dan uji Welch untuk memenuhi syarat uji parametrik one-way ANOVA. Jika hasil uji Brown-Forsythe dan uji Welch memberikan nilai $p<0,05$, maka data dapat dilakukan uji parametrik one-way ANOVA.

Penelitian yang dilakukan berjenis analitik dengan desain eksperimental laboratorik. Penelitian ini telah memperoleh surat persetujuan etik dari Komisi Etik Penelitian Fakultas Kedokteran Gigi Universitas Indonesia (Pembebasan Persetujuan Etik Nomor 14/Ethical Exempted/FKGUI/XII/2019/ amandemen). Penelitian dilakukan di Laboratorium Biologi Oral dan Departemen Ortodonsia Fakultas Kedokteran Gigi Universitas Indonesia pada bulan Agustus 2020 - September 2020. 


\section{HASIL}

Penelitian diawali dengan melakukan uji reliabilitas interobserver antara peneliti dengan laboran serta uji intraobserver di dua waktu yang berbeda dengan sampel yang sama. Uji dilakukan pada 24 sampel. Uji kesesuaian interobserver memperoleh hasil yang berkisar antara 0,833 hingga 1 yang berarti kesepakatan antar peneliti tinggi. Uji kesesuaian intraobserver menunjukkan hasil 1 yang berarti konsistensi peneliti yang sangat baik dalam melakukan penelitian berulang. Karena kedua uji tersebut telah dipenuhi, maka penelitian dilanjutkan dengan uji hitung koloni bakteri.

BiofilmbakteriStreptococcusmutans(ATCC 25175) yang terbentuk pada email di sekitar braket ortodonti pada penelitian ini, dipaparkan dengan empat macam gel yaitu gel chitosan $\mathrm{A}$, gel chitosan $\mathrm{B}$, gel chitosan $\mathrm{C}$, dan gel klorheksidin diglukonat $0,2 \% \quad(\mathrm{CHX})$ sebagai kontrol. Hasil paparan kemudian diuji untuk menilai efektivitas antibakteri keempat gel tersebut melalui uji hitung koloni bakteri. Hasil uji hitung koloni bakteri dinyatakan dalam satuan Colony Forming Unit (CFU)/ml.

Tabel 1. Nilai rerata jumlah koloni bakteri Streptococcus mutans (ATCC 25175) setelah aplikasi gel chitosan A, gel chitosan B, gel chitosan C, dan gel kontrol CHX (CFU/ml)

\begin{tabular}{lcccc}
\hline Kelompok & Rerata & Simpang baku (SD) & Minimum & Maksimum \\
\hline Gel chitosan A & $10,05 \times 10^{6}$ & $1,12 \times 10^{6}$ & $8,88 \times 10^{6}$ & $11,22 \times 10^{6}$ \\
Gel chitosan B & $9,72 \times 10^{6}$ & $2,69 \times 10^{6}$ & $6,90 \times 10^{6}$ & $12,55 \times 10^{6}$ \\
Gel chitosan C & $10,96 \times 10^{6}$ & $3,11 \times 10^{6}$ & $7,69 \times 10^{6}$ & $14,22 \times 10^{6}$ \\
Gel kontrol CHX & $4,35 \times 10^{6}$ & $1,23 \times 10^{6}$ & $3,05 \times 10^{6}$ & $5,64 \times 10^{6}$ \\
\hline
\end{tabular}

Hasil uji hitung koloni bakteri dari empat kelompok perlakuan gel yang berbeda menunjukkan bahwa rerata jumlah koloni bakteri $\mathrm{S}$. mutans hidup terendah hingga tertinggi adalah gel $\mathrm{CHX}\left(4,35 \times 10^{6} \mathrm{CFU} / \mathrm{ml}\right)$, gel chitosan $\mathrm{B}\left(9,72 \times 10^{6}\right.$ $\mathrm{CFU} / \mathrm{ml})$, gel chitosan $\mathrm{A}\left(10,05 \times 10^{6} \mathrm{CFU} / \mathrm{ml}\right)$, dan gel chitosan $C\left(10,96 \times 10^{6} \mathrm{CFU} / \mathrm{ml}\right)$ sehingga dapat disimpulkan bahwa urutan nilai efektivitas antibakteri paling rendah hingga paling tinggi adalah gel chitosan $\mathrm{C}$, gel chitosan $\mathrm{A}$, gel chitosan $\mathrm{B}$, dan gel kontrol $\mathrm{CHX}$ (Tabel 1). Uji normalitas menggunakan uji Shapiro-Wilk sebelum dilakukan uji statistik untuk menguji hipotesis penelitian, dengan hasil sebaran data membentuk distribusi normal $(p>0,05)$. Uji parametrik one-way ANOVA dilakukan untuk membandingkan jumlah koloni bakteri Streptococcus mutans sesudah aplikasi gel chitosan A, gel chitosan B, gel chitosan C, dan gel kontrol $\mathrm{CHX}$. Untuk menguji varians data, dilakukan uji Homogenity of Variance dan didapatkan nilai 0,013 . Oleh karena nilai $p<0,05$, maka dapat disimpulkan bahwa varians data tidak sama atau data tidak homogen sehingga diperlukan uji homogenitas alternatif yaitu uj Brown-Forsythe dan uji Welch. Dari kedua uji tersebut didapatkan nilai $p<0,05$ sehingga dapat disimpulkan bahwa terdapat perbedaan efektivitas antibakteri antarkelompok gel. Setelah syarat uji parametrik dipenuhi, data diuji lebih lanjut dengan uji parametrik one-way ANOVA.

Tabel 2. Hasil uji one way ANOVA

\begin{tabular}{cccccc}
\hline & Sum of squares & df & Mean square & F & Nilai $p$ \\
\hline Between Groups & 161253749999999,970 & 3 & 53751249999999,990 & \multirow{2}{*}{0.916} & 0.000 \\
Within Groups & 98484700000000,000 & 20 & 4924235000000,000 & & \\
\hline Total & 259738449999999,970 & 23 & & & \\
\hline
\end{tabular}

Uji parametrik one-way ANOVA didapatkan nilai $p \leq 0,05$ yang menunjukkan bahwa hipotesis null, ditolak artinya terdapat perbedaan efektivitas antibakteri yang bermakna antara empat kelompok gel antibakteri tersebut yaitu gel chitosan $A$, gel chitosan $\mathrm{B}$, gel chitosan $\mathrm{C}$, dan gel kontrol $\mathrm{CHX}$.
Kemudian dari hasil tersebut, uji statistik PostHoc dilakukan untuk mengetahui kelompok manakah yang memiliki perbedaan bermakna dalam efektivitas antibakterinya. Uji statistik PostHoc yang digunakan adalah uji Least Significant Difference (LSD). 
Tabel 3. Hasil uji least significant difference gel chitosan A

\begin{tabular}{lc}
\hline \multicolumn{1}{c}{ Kelompok eksperimental } & p \\
\hline Gel chitosan A vs gel kontrol CHX & 0,000 \\
Gel chitosan A vs gel chitosan B & 0,802 \\
Gel chitosan A vs cel chitosan C & 0,487 \\
\hline
\end{tabular}

Hasil uji LSD didapatkan nilai $p<0,05$ pada uji antar kelompok perlakuan gel chitosan A dibandingkan dengan kelompok kontrol gel $\mathrm{CHX}$ yang berarti terdapat perbedaan efektivitas antibakteri yang bermakna antara gel chitosan A dibandingkan dengan gel kontrol $\mathrm{CHX}$. Dalam hal ini, gel chitosan A dinilai kurang efektif jika dibandingkan dengan gel kontrol $\mathrm{CHX}$.

Uji antar kelompok perlakuan gel chitosan A dibandingkan dengan kelompok perlakuan gel chitosan $B$ dan gel chitosan $C$ memperlihatkan $p>0,05$ yang berarti tidak terdapat perbedaan efektivitas antibakteri yang bermakna antara gel chitosan $A$ dibandingkan dengan gel chitosan $B$ dan gel chitosan $C$. Dalam hal ini, gel chitosan $A$ dinilai memiliki efektivitas yang sama dengan gel chitosan B dan gel chitosan C.

Tabel 4. Hasil uji least significant difference gel chitosan B

\begin{tabular}{lc}
\hline \multicolumn{1}{c}{ Kelompok eksperimental } & p \\
\hline Gel chitosan B vs gel chitosan A & 0,802 \\
Gel chitosan B vs gel kontrol CHX & 0,000 \\
Gel chitosan B vs gel chitosan C & 0,347 \\
\hline
\end{tabular}

Hasil uji LSD didapatkan nilai $p<0,05$ pada uji antar kelompok perlakuan gel chitosan B dibandingkan dengan kelompok kontrol gel $\mathrm{CHX}$ yang berarti terdapat perbedaan efektivitas antibakteri yang bermakna antara gel chitosan $\mathrm{B}$ dibandingkan dengan gel kontrol $\mathrm{CHX}$. Dalam hal ini, gel chitosan B dinilai kurang efektif jika dibandingkan dengan gel kontrol $\mathrm{CHX}$.

Uji antar kelompok perlakuan gel chitosan B dibandingkan dengan kelompok perlakuan gel chitosan $C$ memperlihatkan nilai $p>0,05$ yang berarti tidak terdapat perbedaan efektivitas antibakteri yang bermakna antara gel chitosan $\mathrm{B}$ dibandingkan dengan gel chitosan C. Dalam hal ini, gel chitosan B dinilai memiliki efektivitas yang sama dengan gel chitosan $\mathrm{C}$.

Hasil uji LSD didapatkan nilai $p<0,05$ pada uji antar kelompok perlakuan gel chitosan C dibandingkan dengan kelompok kontrol gel $\mathrm{CHX}$ yang berarti terdapat perbedaan efektivitas
Tabel 5. Hasil uji least significant difference gel chitosan C

\begin{tabular}{lc}
\hline \multicolumn{1}{c}{ Kelompok eksperimental } & p \\
\hline Gel chitosan C vs gel chitosan A & 0,802 \\
Gel chitosan C vs gel kontrol CHX & 0,000 \\
Gel chitosan C vs gel chitosan B & 0,347 \\
\hline
\end{tabular}

*Gel Chitosan A : 50-80 kDa, Gel Chitosan B : 50-150 kDa, Gel Chitosan C : 190-310 kDa

antibakteri yang bermakna antara gel chitosan C dibandingkan dengan gel kontrol CHX. Dalam hal ini, gel chitosan $\mathrm{C}$ dinilai kurang efektif jika dibandingkan dengan gel kontrol $\mathrm{CHX}$.

\section{PEMBAHASAN}

Faktor-faktor yang dapat memengaruhi efektivitas antibakteri chitosan pada empat kelompok perlakuan selain berat molekul yang dikontrol sehingga tidak memengaruhi efektivitas antibakteri gel chitosan pada penelitian ini. Konsentrasi chitosan 3\% w/w dipilih oleh peneliti berdasarkan uji eksperimental di laboratorium yaitu bahwa konsentrasi $3 \% \mathrm{w} / \mathrm{w}$ merupakan konsentrasi yang paling ideal dalam formulasi obat topikal oral jika diaplikasikan pada ketiga berat molekul yang berbeda.

Hal ini sesuai dengan penelitian Rajabnia et.al. yaitu konsentrasi minimum chitosan untuk menghambat Streptococcus mutans adalah 2\% $w / w$ dan seiring meningkatnya konsentrasi, sifat antibakterinya akan semakin meningkat. ${ }^{16} \mathrm{Hal}$ ini juga sesuai dengan penelitian Marcos Fernandez et.al. yaitu formulasi gel chitosan untuk aplikasi topikal terwujud dengan konsentrasi yang tepat dan berat molekul yang sesuai. ${ }^{17}$

Chitosan yang digunakan pada penelitian ini adalah chitosan bubuk yang larut dalam asam lemah dengan $\mathrm{pH}$ di bawah nilai $\mathrm{pKa}$ chitosan yaitu 6,3 . Pelarut chitosan yang digunakan pada penelitian ini adalah larutan asam asetat $1 \%$. Asam asetat merupakan asam lemah dalam bentuk larutan, molekulnya terdisosiasi menjadi ion $\mathrm{H}^{+}$ (kation) dan ion $\mathrm{CH}_{3} \mathrm{COO}^{-}$(anion). Saat chitosan dilarutkan dengan asam asetat, gugus amin $\left(\mathrm{NH}_{2}\right)$ dari chitosan berikatan dengan kation dari asam asetat dan membentuk suatu polielektrolit kationik polikation $\left(\mathrm{NH}_{3}^{+}\right)$sehingga muatan positif tersebut dapat berikatan dengan permukaan negatif pada bakteri yaitu asam lipoteikoat yang terdapat pada dinding sel bakteri Streptococcus mutans. ${ }^{18}$ 
Hal tersebut sesuai dengan penelitian Ren et. al. yang pernah memformulasikan gel chitosan. ${ }^{19}$ Pelarut paling baik untuk chitosan adalah asam format, namun asam format tidak diperuntukkan untuk bahan pangan sehingga asam asetat merupakan pilihan pelarut yang ideal bagi chitosan yang sesuai dengan tujuannya sebagai agen profilaksis topikal berupa gel untuk aplikasi di daerah oral.

Chitosan menunjukkan efek antibakteri yang lebih kuat pada $\mathrm{pH}$ yang lebih rendah sehingga gel chitosan dalam penelitian ini memiliki $\mathrm{pH}$ berkisar antara 5,8-6,0. ${ }^{12}$ Pemilihan $\mathrm{pH}$ tersebut dilakukan berdasarkan penelitian sebelumnya oleh Ren et.al. ${ }^{19}$ Meskipun $\mathrm{pH}$ yang lebih rendah dapat memberikan efek antimikroba yang lebih baik, namun gel ini diformulasikan sebagai agen profilaksis topikal untuk email sehingga nilai $\mathrm{pH}$ kritis enamel $(\mathrm{pH} 5,5)$ perlu diperhatikan. ${ }^{20} \mathrm{Gel}$ chitosan harus disimpan pada suhu lemari pendingin $\left(2-8^{\circ} \mathrm{C}\right)$ karena suhu memengaruhi kadar air pada gel chitosan. Suhu udara dapat memengaruhi rasio degradasi rantai molekul chitosan. Jika hal tersebut tidak terjaga, gel chitosan akan cepat mencair. ${ }^{21}$

Hasil penelitian ini menunjukkan bahwa gel chitosan A (50-80 kDa), gel chitosan $B(50-$ $150 \mathrm{kDa})$, dan gel chitosan C (190-310 kDa) mengurangi jumlah koloni bakteri Streptococcus mutans pada permukaan enamel sekitar braket ortodonti dilihat dari jumlah koloni bakteri hasil uji gel chitosan $A\left(10,05 \times 10^{6} \mathrm{CFU} / \mathrm{ml}\right)$, gel chitosan $B$ $\left(9,72 \times 10^{6} \mathrm{CFU} / \mathrm{ml}\right)$, dan gel chitosan $\mathrm{C}\left(10,96 \times 10^{6}\right.$ $\mathrm{CFU} / \mathrm{ml}$ ), kemampuan menghambat antara gel satu dengan yang lainnya tidak memiliki perbedaan yang bermakna. Hal tersebut menjelaskan bahwa gel chitosan A, gel chitosan $B$, dan gel chitosan $C$ memiliki efektivitas antibakteri yang sama.

Hal tersebut dapat terjadi terjadi karena chitosan memiliki berat molekul yang rendah, maupun chitosan berat molekul tinggi memiliki efek bakteriostatik terhadap bakteri Streptococcus mutans meskipun keduanya memiliki mekanisme yang berbeda. Sudarshan et. al. dan Zheng at. al. cit. in Cheung et. al. memaparkan tentang perkiraan mekanisme antibakteri yang berhubungan dengan berat molekul chitosan. Chitosan berat molekul rendah dapat mempenetrasi dinding sel bakteri, berikatan dengan DNA, dan menghambat transkripsi DNA dan sintesis mRNA dari bakteri, sedangkan chitosan berat molekul tinggi dapat berikatan dengan komponen bermuatan negatif dari dinding sel bakteri sehingga terbentuk lapisan impermeabel di sekitar sel bakteri. Hal tersebut menyebabkan terjadinya perubahan permeabilitas sel dan menghalangi transportasi molekul seperti nutrisi masuk ke dalam sel bakteri. ${ }^{22}$

Hasil penelitian ini menunjukkan jumlah koloni bakteri hasil uji gel chitosan B (50-150 kDa) yaitu $9,72 \times 10^{6} \mathrm{CFU} / \mathrm{ml}$ lebih rendah daripada hasil uji gel chitosan $\mathrm{A}(50-80 \mathrm{kDa})$ yaitu $10,05 \times 10^{6} \mathrm{CFU} /$ $\mathrm{ml}$, meskipun secara statistik tidak menunjukkan perbedaan yang bermakna. Hal ini dapat terjadi karena rentang berat molekul yang dimiliki oleh gel $B$ lebih besar sehingga terdapat potensi antibakteri yang lebih luas. Hal tersebut dapat terjad karena adanya kombinasi mekanisme antibakteri chitosan berat molekul yang lebih rendah dengan mekanisme antibakteri berat molekul yang lebih tinggi. Hal ini terjadi karena chitosan berat molekul rendah maupun chitosan berat molekul tinggi memiliki mekanisme antibakteri meskipun bekerja dengan cara yang berbeda. ${ }^{22}$

Chitosan membentuk lapisan antibacterial barrier pada permukaan email gigi karena spektrum antimikrobanya yang luas sehingga mampu mengurangi adhesi bakteri $S$. mutans pada permukaan email. ${ }^{23,24,25} \mathrm{Hal}$ ini dibuktikan dari adanya penurunan jumlah koloni bakteri $S$. mutans pada biofilm yang terbentuk pada email gigi sampel. Hal ini berlaku bagi chitosan dengan berat molekul yang rendah maupun tinggi.

Hasil ini sesuai dengan penelitian Abedian et. al. yang menguji Konsentrasi Hambat Minimum (KHM) chitosan dengan berat molekul yang berbeda yaitu $0,62 \mathrm{mg} / \mathrm{ml}$ untuk berat molekul rendah (100 $\mathrm{kDa})$ dan tinggi $(600-800 \mathrm{kDa})$ terhadap bakteri $S$. mutans sehingga dapat dijelaskan bahwa chitosan berat molekul rendah dan tinggi memiliki efek bakteriostatik yang sama terhadap S. mutans. ${ }^{26}$

Hasil ini juga sesuai dengan penelitian Kim dan Shin yang menguji efek inhibisi resin komposit yang mengandung chitosan dengan berat molekul yang berbeda yaitu chitosan berat molekul rendah (50-190 kDa), sedang (190-310 kDa), dan tingg (310-375 kDa) terhadap bakteri S. mutans dengan nilai jumlah koloni bakteri yaitu $0,53 \times 10^{9} \mathrm{CFU}$, $0,19 \times 10^{\circ} \mathrm{CFU}$, dan $0,63 \times 10^{\circ} \mathrm{CFU}$ secara berurutan. Hasil penelitiannya menunjukkan bahwa chitosan berat molekul sedang, dan chitosan berat molekul tinggi memiliki kemampuan menghambat yang 
sama terhadap S. mutans. ${ }^{27}$ Hasil diatas berbeda dengan penelitian Thongaroon et. al. yang meneliti efektivitas antimikroba mouthwash chitosan terhadap bakteri Streptococcus mutans dengan berat molekul yang berbeda yaitu $30 \mathrm{kDa}, 890 \mathrm{kDa}$, dan $1700 \mathrm{kDa}$. Hasil penelitiannya menunjukkan bahwa chitosan dengan berat molekul yang lebih rendah yaitu $30 \mathrm{kDa}$ dan $890 \mathrm{kDa}$ memiliki efektivitas antibakteri yang lebih tinggi daripada berat molekul yang lebih tinggi yaitu $1700 \mathrm{kDa} .{ }^{28} \mathrm{Hal}$ tersebut dapat terjadi karena chitosan dengan berat molekul yang lebih rendah memiliki ukuran rantai yang lebih kecil sehingga mobilitas dan interaksi ionik molekul dengan permukaan membran bakteri dapat terjadi dengan lebih mudah daripada chitosan dengan berat molekul yang lebih besar. ${ }^{11}$

Hal tersebut pun didukung oleh bentuk fisik chitosan yang digunakan yaitu liquid di mana chitosan dalam bentuk liquid memiliki potensi antibakteri yang lebih baik daripada chitosan dalam bentuk semi-solid karena molekulnya berdisasosiasi di dalam larutan. Chitosan dalam bentuk liquid menunjukkan kemampuan konformasi molekul yang tinggi yaitu pengaturan struktur atom yang beradaptasi bebas di dalam molekul dan bersifat reversible sehingga muatan positif yang dapat berikatan dengan permukaan negatif bakteri lebih banyak. Hal ini menjelaskan alasan bahwa chitosan larut air dan chitosan derivatif memiliki kemampuan inhibisi terhadap bakteri yang lebih baik. ${ }^{12}$

Hasil penelitian ini juga menunjukkan bahwa gel kontrol yaitu gel klorheksidin diglukonat $0,2 \%$ $\left(4,35 \times 10^{6} \mathrm{CFU} / \mathrm{ml}\right)$ memiliki efektivitas antibakteri yang berbeda bermakna dengan ketiga gel chitosan yang diuji yaitu gel chitosan $\mathrm{A}\left(10,05 \times 10^{6} \mathrm{CFU} / \mathrm{ml}\right)$, gel chitosan $B\left(9,72 \times 10^{6} \mathrm{CFU} / \mathrm{ml}\right)$, dan gel chitosan

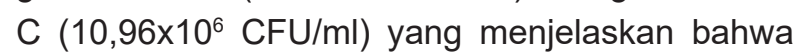
gel chitosan $A$, gel chitosan $B$, dan gel chitosan C memiliki kemampuan antibakteri terhadap bakteri Streptococcus mutans pada permukaan email sekitar braket ortodonti, namun lebih rendah dari kemampuan gel kontrol klorheksidin diglukonat $0,2 \%$. Ini menjelaskan bahwa sifat antibakteri chitosan dan klorheksidin berbeda.

Chitosan bersifat bakteriostatik yaitu menghambat pertumbuhan bakteri sedangkan klorheksidin bersifat bakteriostatik pada konsentrasi rendah dan bersifat bakteriosida yaitu membunuh bakteri pada konsentrasi tinggi. Konsentrasi klorheksidin yang digunakan pada penelitian ini adalah $0,2 \%$ di mana konsentrasi tersebut dianggap sebagai konsentrasi yang ideal dalam menghambat pembentukan plak. $^{29}$ Chitosan dan klorheksidin dalam penelitian ini dibandingkan dalam bentuk gel. Gel chitosan merupakan salah satu bentuk sediaan semi-solid dari chitosan. Molekul chitosan dalam bentuk semisolid memiliki ikatan cross-linking kovalen yaitu terbentuknya suatu ikatan kovalen antara tangantangan bermuatan positif tersebut secara crosslinking sehingga jumlah tangan molekul bermuatan positifnya lebih sedikit. ${ }^{12}$ Hal tersebut dapat menyebabkan gel chitosan memiliki efektivitas yang lebih rendah dari pada gel klorheksidin diglukonat $0,2 \%$. Selain bentuknya, chitosan yang digunakan pada penelitian ini adalah chitosan yang larut dalam asam lemah.

Efektivitas antibakteri chitosan yang larut asam berbeda dengan chitosan yang larut air yaitu chitosan yang memiliki molekul yang lebih kecil sehingga mampu berpenetrasi ke dalam sel bakteri dengan lebih baik. ${ }^{22}$ Hasil ini sesuai dengan penelitian de Luca et.al. yang meneliti sifat antimikroba dari varnish propolis dengan konsentrasi propolis yang berbeda, ekstrak propolis, varnish chitosan, dan varnish klorheksidin diglukonat $0,12 \%$ terhadap bakteri kariogenik yang salah satunya adalah bakteri $S$. mutans (ATCC 25175). Hasil penelitiannya menunjukkan bahwa varnish chitosan memiliki hasil zona inhibisi paling rendah pada bakteri Streptococcus mutans (ATCC 25175) yaitu $10,4 \mathrm{~mm} \cdot{ }^{30}$

Varnish chitosan merupakan chitosan dalam bentuk semi-solid sehingga efektivitas antibakteri chitosan lebih rendah daripada efektivitas antibakteri klorheksidin diglukonat $0,2 \%$. Hasil ini berbeda dengan penelitian yang dilakukan oleh Uraz et.al. dan Mhaske et.al. yang meneliti tentang obat kumur chitosan 2\%, klorheksidin diglukonat $0,2 \%$, dan kombinasi keduanya. Hasil penelitiannya menunjukkan bahwa dalam waktu 4 hari periode pembentukan plak, tidak ada perbedaan yang signifikan dari nilai indeks plak (PI) maupun nilai indeks gingival $(\mathrm{Gl})$ antara obat kumur chitosan $2 \%$ dan klorheksidin diglukonat $0,2 \% .^{31,32}$

Hal tersebut mungkin terjadi karena chitosan yang digunakan dalam kedua penelitian tersebut adalah chitosan berat molekul tinggi (190$310 \mathrm{kDa}$ ) yang dapat larut air sehingga chitosan dapat berikatan dengan komponen bermuatan 
negatif dari dinding sel bakteri yang menyebabkan transportasi molekul ke dalam sel bakteri menjadi terhambat. ${ }^{22} \mathrm{Hal}$ serupa diungkapkan dalam penelitian Hasriati et. al., namun penelitian ini menggunakan konsentrasi obat kumur chitosan yang berbeda yaitu $1 \%$ dan chitosan berat molekul tinggi yang larut asam. ${ }^{33}$

Berat molekul chitosan yang digunakan dalam penelitian ini memiliki batasan yang tidak jelas antara satu dengan yang lainnya sehingga memberikan hasil yang masih inkonsisten. Penelitian selanjutnya diharapkan dapat memberikan hasil yang lebih konsisten.

\section{SIMPULAN}

Efektivitas antibakteri gel chitosan dengan berat molekul berbeda terhadap jumlah koloni bakteri Streptococcus mutans pada permukaan email sekitar braket ortodonti adalah sama besar, namun lebih rendah daripada efektivitas antibakteri gel klorheksidin diglukonat $0,2 \%$ pada studi ini.

\section{DAFTAR PUSTAKA}

1. Dimberg L, Arnrup K, Bondemark L. The impact of malocclusion on the quality of life among children and adolescents: a systematic review of quantitative studies. Eur. 2015 Jun 1;37(3):238-47. DOI: 10.1093/ejo/cju046

2. Silva LFG e, Thomaz EBAF, Freitas HV, Pereira ALP, Ribeiro CCC, Alves CMC. Impact of malocclusion on the quality of life of Brazillian adolescence : a population-based study. PLoS One. 2016;11(9): e0162715. DOI: 10.1371/ journal.pone.0162715

3. Dutra SR, Pretti H, Martins MT, Bendo CB, Vale MP. Impact of malocclusion on the quality of life of children aged 8 to 10 years. Dental Press J Orthod. 2018 Mar-Apr;23(2):46-53. DOI:10.1590/2177-6709.23.2.046-053.oar

4. Liu BC, Lee I, Lo L, Ko EW. Investigate the oral health impact and quality of life on patients with malocclusion of different treatment needs. Biomedical J. 2019 Dec;42:422-29. DOI: 10.1016/j.bj.2019.05.009

5. Heymann GC, Grauer D. A contemporary review of white spot lesions in orthodontics: white spot lesions in orthodontics. J Esthet Restor Dent. 2013 Apr;25(2):85-95. DOI:

\subsection{1/jerd.12013}

6. Eltayeb MK, Ibrahim YE, Karim IAE, Sanhouri NM. Distribution of white spot lesions among orthodontic patients attending teaching institutes in Khartoum. BMC Oral Health. 2017 May;88.

7. Biria $M$, Jafary M. A review on preventive measures and treatment of white spot lesions in patients with fixed orthodontic appliances. J Dent School. 2014 Aug;33(1):106-17. DOI:10.22037/jds.v33i1.24765

8. Restrepo M, Bussaneli DG, Jeremias F, Cordeiro R, Raveli D, Magalhães $A$, et al. Control of white spot lesions with use of fluoride varnish or chlorhexidine gel during orthodontic treatment a randomized clinical trial. J Clin Pediatr Dent. 2016 Oct;40(4):274-80.

9. Sajjan P, Laxminarayan N. Chlorhexidine as an antimicrobial agent in dentistry - a review. OHDM. 2016 Apr;15(02):93-100.

10. Azmana M, Mahmood S, Hilles AR, Rahman A, Arifin MAB, Ahmed S. A review on chitosan and chitosan-based bionanocomposites : promising material for combatting global issues and its applications. Int. J. Biol. 2021 Aug;185:832-48. DOI: $10.1016 /$ j.ijbiomac.2021.07.023

11. Ardean C, Davidescu CM, Nemeş NS, Negrea A, Ciopec M, Duteanu N, Negrea P, DudaSeiman D, Musta V. Factors influencing the antibacterial activity of chitosan and chitosan modified by functionalization. Int J Mol Sci. 2021 Jul;22(14):7449. DOI: 10.3390/ijms22147449

12. Yilmaz Atay H, Jana S, Jana S. Antibacterial activity of chitosan-based systems. Functional Chitosan. 2020 Mar 6:457-89. DOI: 10.1007/978-981-15-0263-7 15

13. Priya K Y, Prathibha K M. Methods of collection of saliva - a

14. review. Int J Oral Health Dent. 2017 Sep;3(3):149-53. DOI: 10.18231/2395499X.2017.0032

15. Khamverdi Z, Farhadian F, Khazaei S, Adabi $M$. Efficacy of chitosan-based chewing gum on reducing salivary $S$. mutans counts and salivary $\mathrm{pH}$ : A randomized clinical trial. Acta Odontol Scand. 2021 Nov;79(4):268-74. DOI: 10.1080/00016357.2020.1836392.

16. Ren Q, Li Z, Ding L, Wang X, Niu Y, Qin X, et al. Anti-biofilm and remineralization effects of chitosan hydrogel containing amelogenin- 
derived peptide on initial caries lesions. Regenerative Biomaterials. 2018 Mar 1;5(2):69-76. DOI: 10.1093/rb/rby005

17. Rajabnia R, Ghasempour M, Gharekhani S, Gholamhoseinnia S, Soroorhomayoon S. AntiStreptococcus mutans property of a chitosan: containing resin sealant. J Int Soc Prev Community Dent 2016 Jan-Feb;6(1):49-53. DOI: 10.4103/2231-0762.175405

18. Marcos Fernandez, Carlos von Plessing, Galo Cardenas. Preparation and Characterization of Chitosan Gels. J Chil Chem Soc. 2006;51:10224. DOI: 10.4067/S0717-97072006000400005

19. Bretado-Aragón LA, Jiménez-Mejía R, LópezMeza JE, Loeza-Lara PD. Composites of silverchitosan nanoparticles a potential source for new antimicrobial therapies. Revista Mexicana de Ciencias Farmaceuticas. 2018 Oct;47(4):7-25.

20. Ren Q, Ding L, Li Z, Wang X, Wang K, Han $S$, et al. Chitosan hydrogel containing amelogenin-derived peptide: Inhibition of cariogenic bacteria and promotion of remineralization of initial caries lesions. Arch. Oral Biol. 2019 Apr;100:42- 8. DOI: 10.1016/i. archoralbio.2019.02.004.

21. Barac R, Gasic J, Trutic N, Sunaric S, Popovic J, Djekic P, Radenkovic G, Mitic A. Erosive effect of different soft drinks on enamel surface in vitro : application of stylus profilometry. Med Princ Prac. 2015 Jun;24:451-57. DOI: 10.1159/000433435

22. Szymańska E, Winnicka K. Stability of Chitosan-A challenge for pharmaceutical and biomedical applications. Marine Drugs. 2015 Apr 1;13(4):1819-46. DOI: 10.3390/ md13041819

23. Cheung R, Ng T, Wong J, Chan W. Chitosan: An update on potential biomedical and pharmaceutical applications. Marine Drugs. 2015 Aug 14;13(8):5156-86. DOI: 10.3390/ md13085156

24. Tachaboonyakiat W. Antimicrobial applications of chitosan. Chitosan Based Biomaterials. 2017(2):245-74.

25. Costa EM, Silva S, Tavaria FK, Pintado MM. Study of the effects of chitosan upon Streptococcus mutans adherence and biofilm formation. Anaerobe. 2013 Apr;20:27-31. DOI: 10.1016/i.anaerobe.2013.02.002

26. Anggani HS, Perdana RG, Siregar E, Bachtiar
EW. The effect of coating chitosan on porphyromonas gingivalis biofilm formation in the surface of orthodontic mini-implant. J Adv Pharm Technol Res. Jan-Mar 2021;12(1): 848. DOI: 10.4103/japtr.JAPTR 9520

27. Abedian, Zeinab; Jenabian, Niloofar; Moghadamnia, Ali; Zabihi, Ebrahim; Tashakorian, Hamed; Rajabnia, Mahdi; Sadighian, Farahnaz; Bijani, Ali. Antibacterial activity of high-molecular-weight and lowmolecular-weight chitosan upon oral pathogens. J Conserv Dent. 2019 Apr;22(2):169-74.

28. Kim JS, Shin D-H. Inhibitory Effect on streptococcus mutans and mechanical properties of the chitosan containing composite resin. Restor Dent Endod. 2013;38(1):36-42. 23.

29. Thongaroon K, Phonghanyudh A, Surarit R, Kraivaphan $\mathrm{P}$, Niamsiri N. In-vitro antimicrobial activity of chitosan mouthwash against streptococcus mutans and lactobacillus casei. Walailak Procedia. 2019;113:27-8.

30. Samanth DSA, Varghese DSS. The most effective concentration of chlorhexidine as a mouthwash- systematic review. J Pharm Sci. 2017 Feb;9(2):233-36.

31. De Luca MP, Franca JR, Macedo FAFF, Grenho L, Cortes ME, Faraco AAG, et al. Propolis varnish: antimicrobial properties against cariogenic bacteria, cytotoxicity, and sustained-release profile. J Biomed Biotechnol. 2014;1-6. DOI: 10.1155/2014/348647

32. Uraz A, Boynueğri D, Özcan G, Karaduman B, Uç D, Şenel S, et al. Two percent chitosan mouthwash: A microbiological and clinical comparative study. J Dent Scie. 2012 Dec;7(4):342-9. DOI: 10.1016/i. jds.2012.05.003

33. Mhaske SP, Iska D, Ambiti R, Jagga U, Paul U, M Shanmukappa S. Clinicomicrobiological evaluation of $2 \%$ chitosan mouthwashes on dental plaque. $\mathrm{J}$ Contempor Dent Prac. 2018;19(1):94-7. DOI: 10.5005/jpjournals-10024-2218

34. Hasriati E, Anggani HS, Purbiati M, Bachtiar EW. Antibacterial effect of $0.2 \%$ chlorhexidine and $1 \%$ chitosan mouthwash on bacteria during orthodontic miniscrew use. Int J App Pharm. 2020 Jul 20;8-12. DOI: 10.22159/ijap.2020. v12s2.OP-07 